\title{
THE IMPACT OF HUMAN RESOURCE MANAGEMENT PRACTICES ON EMPLOYEE READINESS FOR CHANGE DURING MERGERS AND ACQUISITIONS
}

\section{Abstract}

Embracing constant and continuous change is a necessity for business success. An organisation must be in a continuous state of change readiness. Researchers have confirmed that for organisational readiness, individual employees must also be open, prepared, and ready for change. Researchers and practitioners have both found employee readiness to be a critical factor in successful change efforts. This study presents the impact of employee perception of human resource management practices on employee readiness for change during pre-mergers and acquisitions. A total of 235 employees from the three largest food companies in Istanbul participated in the study. The data was analysed using correlation and regression analysis. The results show that employees' positive perceptions of the company's career development, compensation, and communication practices positively affect their readiness for mergers and acquisitions.

Keywords: human resource management (HRM) practices, career development practices, compensation practices, communication practices, employee readiness for change, mergers and acquisitions (M\&As).

\section{Introduction}

Mergers and acquisitions have become a popular corporate strategy choice for many organisations. Mergers and acquisitions are complex events in organisational life. Although plenty of attention is paid to the legal, financial, and operational elements of mergers and acquisitions, those of human resource management (HRM) are the most neglected. Ironically, 
statistics show that one of the major reasons for the failure of M\&As is the human resources aspect. The uncertainty brought out by poorly managed HR in mergers and acquisitions has been reported as the major reason for failure. In addition to the low success rate, many researchers have found that negative employee reactions to a merger or acquisition may lead to other negative outcomes such as lower levels of job security, lower levels of job satisfaction and less favourable attitudes toward management (e.g. Buono \& Bowditch 1989, Nemanich \& Keller 2007); lower commitment (Fulmer \& Gilkey 1988); a high level of anxiety and stress, fear of a decline in status or career prospects and feelings of being "sold out" (Blake \& Mouton 1985, Ivancevich, Schweiger \& Power 1987); employee resistance preventing synergy realisation (Larsson \& Finkelstein 1999); the undermining of capabilities transfer (Birkinshaw, Bresman \& Håkanson 2000) and integration problems (Björkman, Stahl \& Vaara 2007).

Human resources (HR) must be broadly involved in all phases of M\&A and especially at the pre-mergers and acquisitions stage (Greenspan 2014). Both the acquiring and the acquired company's HR departments have a pivotal role to play in guiding all of their employees through the difficult process that begins with the announcement and ends with the implementation of integration. It should fall to top management from the very beginning to charge HR with the task of devising strategies and a clear road map to tackle all of the issues that can be expected to surface along the route. Top management should also consult their HR people on the human issues of a merger or acquisition before decisions are made (Roij 2014). In general terms, HR practices should be designed to prepare and motivate employees for change.

\section{Literature Review}

\subsection{Employee Readiness for Change}

As it is arguably one of the most important factors involved in employees' initial support for change initiatives, readiness is one of the key terms in change management (Armenakis, Harris \& Field 1999). Readiness for organisational change refers to individuals' beliefs, attitudes and intentions regarding the extent to which changes are needed and the organisation's capacity to successfully undertake these changes (Armenakis, Harris \& Mossholder 1993). Individual readiness can change the direction of any proposed organisational change, as in most cases individuals that have been prepared will end up supporting it. What is more, the implementation 
of change will be smoother and quicker when change agents are working with these employees. Readiness for change begins with an individual's perception of the benefits of change (Prochaska et al. 1994), the risks of failing to change (Armenakis, Harris \& Mossholder 1993) or the demands of externally imposed changes (Pettigrew 1987).

The change-readiness perceptions are believed, in turn, to promote behavioural change (Holt et al. 2007) and thus the further separation of change-readiness perceptions from their consequences (that is, behaviour or intentions). Change readiness is a belief characterising attitudes to a change initiative, whereas intentions represent action-oriented thoughts toward a goal or activity. This is consistent with research into behavioural change, which postulates that individuals go through stages of change beginning with psychological acceptance, such as "buy-in", and moving toward behavioural intentions to engage in behavioural change (Levesque et al. 1999, 2001).

Individual readiness to change is frequently studied within the context of resistance to change. Employee readiness is an important driver of the success of change: initiatives may fail if employees do not believe that change is needed or that the organisation will not be able to change (Cunningham et al. 2002).

\subsection{HRM Practices during Pre-mergers and Acquisitions}

The involvement of HR in mergers and acquisitions, which is a critical factor in their success, has been discussed in numerous studies (e.g., Daniel \& Metcalf 2001, Jeris, Johnson \& Carol 2002). The results are clear: one of the main reasons for the failure of a merger or acquisition is the neglect of human resources. Companies that have failed to recognise the importance of human resources in their organisations and its important role in integration have not been successful. Human issues in mergers and acquisitions, which have very often been the most sensitive, have often been ignored (Vazirani 2012).

Mergers and acquisitions make people on both sides of the transaction nervous. In most cases, employees are uncertain what the deal will mean. They wonder whether and how they will fit into the new organisation (Brief 2009). In the absence of information and clear communication, they feel insecure, stressed and less motivated. HRM professionals have to prepare employees for change, identify and overcome resistance to change, and inspire flexibility and adaptability in their personnel. One of the primary responsibilities of human resource managers is the intense and challenging task of dealing with employee angst and turmoil during such periods of 
change. HR strategies during pre-M\&As should be focused on increasing employees' trust, commitment and motivation.

\subsection{HR Practices (Career Development, Compensation and Communication) and Employee Readiness for Change}

Employees generally view organisational changes as a threat, so that mergers and acquisitions, which are particularly stressful forms of organisational reconfiguration, often generate significant trauma and uncertainty about the future for employees (Morán \& Panasian 2005). Mergers and acquisitions introduce changes in their well-defined career paths that can affect future opportunities in the organisations for which they work. For them, M\&As will often mean lay-offs, relocation, downsizing, restructuring or being assigned to new jobs. They thus find themselves faced with a completely different situation and with the prospect of changes in job profiles and work teams. As a consequence, they may feel very insecure, anxious or even betrayed. The research done by Naveed, Hanif \& Ali (2011) showed that employees who were working in a pre-mergers \& acquisitions environment felt a strong threat to their job security. HR managers should be able to assure their employees that they have a strategy mapped out in advance.

Effective support for career development is important for employees and forms part of a joint strategy with organisations to achieve the resilience required to handle change more effectively. There is evidence, however, that the organisational changes typically described in the literature, such as delayering in a quest for flexibility, have had a negative impact on career progress and resulted in resistance to change (Lips-Wiersma \& Hall 2007). Organisations focus on career development to build engagement during difficult times so that stressed employees have a positive focus on the future (Knight 2014).

Employees' perception of the effort their organisation is making to support their need for career development is important in job satisfaction. Employees may become dissatisfied if they perceive that an organisation does not value their contribution and shows little concern for their developmental needs. If, on the other hand, management endeavours to help employees gain promotion, then higher levels of satisfaction ultimately ensue (Yean \& Yahya 2013). Career advancement provides growth opportunities for employees that increase their stake in the organisation: when they see their career prospects as bright, they are motivated and energised to work harder. If career prospects are promising, a close bond is formed between 
the future of employees and that of the organisation. Employees are therefore likely to identify with it and work hard to make it successful. Lastly, the availability of promising career prospects increases the opportunity cost of leaving the organisation - especially for talented people (Gong \& Chang 2008). In this context, employees' perceptions of an organisation's career practices will send positive signals regarding the extent to which it is willing to take care of their well-being. Employees who believe that management is on their side and that there is a future for them will have higher levels of readiness for change.

Hypothesis 1: Employees' positive perceptions of a company's career-development practices positively affect their readiness for change during pre-mergers and acquisitions.

Behavioural changes on the part of individuals are required for organisational change, and compensation systems affect behaviour. The results of many studies have supported the assertion that compensation is one of the strongest determinants of employee attitudes, motivation and behaviour (Gerhart \& Milkovich 1992). Compensation has been cited as having an important influence in recruiting new employees and retaining existing ones (Steers 1977). Generous rewards tend to retain people because high reward levels seem to lead to high satisfaction, commitment and loyalty (Ibrahim \& Boerhaneoddin 2010). It is therefore important to consider the role compensation systems play in facilitating organisational change through their effect on the motivation and productivity of individuals. First, they encourage individuals to get on board with change and to learn, among other things, what the new goal or mission of the organisation is and how their decisions and behaviour will affect the organisation's progress toward that goal. Second, they help overcome organisational inertia and opposition to change. Finally, they represent one way to provide individuals with benefits that are sufficient to outweigh the perceived costs of change (Wruck 2000).

Hypothesis 2: Employees' positive perceptions of the company's compensation practices positively affect readiness for change during mergers and acquisitions.

Communication is a key factor in change management. Fisher (2004) said that one of the key lessons learned from M\&A transitions is that clear communication lines upward, and positive control downward, should be established immediately. Guirdham (1999) agrees that managers of all types, business executives, members of the professions and people at work 
generally need to be able to communicate with each other successfully in M\&As.

Any failure to communicate either before or during a merger leaves employees uncertain about their future, which is known to be more stressful than change itself. With this mood upon them they will tend to turn to their own channels of communication for comfort, which means reliance on rumours and other means of informal communication (Rosnow 1988). Buono and Bowditch (1989) mention that rumour mills and the grapevine work overtime during mergers and acquisitions, which leads to more anxiety and, in many cases, to counterproductive behaviour. Marks and Mirvis (1986) state that insufficient and low quality communication leaves rumours free to multiply. These rumours, which are often based on fears rather than on reality, can significantly exacerbate employee anxiety, tension and stress.

The change message that is communicated to employees is a decisive factor influencing readiness for change (Armenakis, Harris \& Field 1999). Stahl and Kuhlmann (2002) argue that communication is a vital part of any process of change and that it is a matter of particular urgency in M\&As to counter the "merger syndrome" among employees. Communication, because it informs them of the changes in their environment and so reduces uncertainty and ambiguity, can help employees to manage the merger syndrome. At this point, the role of HR in conveying the management message and matching the medium of communication to the audience becomes all important. Communication reduces the energy expended by employees in searching for answers to their questions, helps them to accept change and offers an explanation of the underlying rationale. The literature on mergers and acquisitions suggests that the only way for management to deal with the anxiety and uncertainty following a merger or acquisition announcement is to communicate with employees as soon as possible about all the anticipated effects of change (Schweiger \& Denisi 1991). Bordia and his team (2004) found that change communication can facilitate openness and positive attitudes towards change, while the investigation conducted by Allen and his colleagues (2007) showed that insofar as it addressed employees' uncertainty regarding strategic and job-related issues, good change communication was positively related with employees' openness to change.

Hypothesis 3: Employees' positive perceptions of the company's communication practices positively affect their readiness for change during mergers and acquisitions. 


\section{Research Methods}

\subsection{Procedure and Participants}

The data were collected between December 2013 and February 2014 from three privately owned food companies in Istanbul. All three companies had been through a horizontal merger in 2012. The survey was sent to 422 white collar employees, of which 235 responded. This led to an average response rate of $56 \%$. Of the respondents, $63 \%$ were male and $37 \%$ were female. The sample characteristics of the participants are listed in detail in Table 1.

Table 1. Sample Characteristics of Participants

\begin{tabular}{l|l|c|c}
\hline \multicolumn{1}{c|}{ Variable } & \multicolumn{1}{|c|}{ Group } & $N$ & Percentage \\
\hline \multirow{2}{*}{ Age } & Up to 30 years & 32 & 13.6 \\
\cline { 2 - 4 } & 31 to 40 years & 78 & 33.2 \\
\cline { 2 - 4 } & 41 to 50 years & 95 & 40.4 \\
\cline { 2 - 4 } & 51 to 60 years & 30 & 12.8 \\
\hline \multirow{2}{*}{ Gender } & Male & 148 & 63 \\
\cline { 2 - 4 } & Female & 87 & 37 \\
\hline \multirow{2}{*}{ Marital status } & Single & 61 & 26 \\
\cline { 2 - 4 } & Married & 174 & 74 \\
\hline \multirow{2}{*}{ Overall work experience } & Up to 10 years & 62 & 26.4 \\
\cline { 2 - 4 } & 11 to 21 years & 52 & 51.5 \\
\cline { 2 - 4 } & 21 and up & 114 & 22.1 \\
\hline \multirow{2}{*}{ Job level } & Entry level & 73 & 20.4 \\
\cline { 2 - 4 } & Mid-level & 31.1 \\
\cline { 2 - 4 } & Senior level & 48.5 \\
\hline
\end{tabular}

Source: author's own research.

\subsection{Instrumentation}

The questionnaire used in this study was three pages long and had three sections. On the cover page, section one explained the purpose and the nature of the study. Section two included 35 items composed of the measures of four variables: HR compensation practices, career development, communication and employee readiness for change. Section three included demographic questions such as age, gender and length of service, as well as information on the type of merger and acquisition that they had experienced. All of the questions were translated into Turkish for semantic 
and syntactic equivalence by two research associates. Minor editing was completed following the translations. This study used a five-point Likert Scale $(1=$ completely disagree to $5=$ completely agree) for compensation, communication and employee readiness for change. The responses for career development ranged from 1 (not accurate at all) to 4 (very accurate).

\subsection{Measures}

Employee readiness for change was measured by Hanpachern's 14-item scale, which was slightly modified following Madsen, Miller and John (2005) so that the items would be clear to participants. Change communication was assessed using nine items based on the characteristics of effective change communication as detailed in existing measures of the quality of change communication (Miller \& Monge 1985, Miller, Johnson \& Grau 1994). Compensation practices were measured by Snell and Dean's eight items (1992), while career development was measured by four items from Delery and Doty's career advancement scale (1996).

\subsection{Statistical Analysis}

To test the impacts of the model variables, the factors were computed and reliability analyses were performed for all of the factors using SPSS version 21.0. The factor analysis was accomplished using principal component factor analysis followed by varimax rotation. Following examination of the loadings under each factor it was found that none of the items had low factor loadings. For this reason, none of the factor loadings were excluded from the analysis.

\section{Results}

The correlation coefficients of the construct variables are shown in Table 2.

Table 2: Descriptive Statistics and Correlations among Key Variables

\begin{tabular}{l|c|c|c|c|c|c}
\hline \multicolumn{1}{c|}{ Variable } & Mean & SD & 1 & 2 & 3 & 4 \\
\hline 1. Career development practices & 3.464 & 0.63 & 1 & & & \\
\hline 2. Compensation practices & 3.562 & 0.74 & $0.589^{* *}$ & 1 & & \\
\hline 3. Communication practices & 3.771 & 1.04 & $0.605^{* *}$ & $0.735^{* *}$ & 1 & \\
\hline 4. Employee readiness for change & 3.923 & 1.21 & $0.183^{* *}$ & $0.233^{* *}$ & $0.328^{* *}$ & 1 \\
\hline
\end{tabular}
*** $p<0.01$.

Source: author's own research. 
To test Hypothesis 1, a simple regression analysis was conducted to examine the impact of employees' positive perceptions of the company's career development practices on readiness for change. The results showed a significant positive relationship between these two variables $(p=0.002)$ (Table 3).

To test Hypothesis 2, a simple regression analysis was conducted to examine the impact of employees' positive perceptions of the company's compensation practices on readiness for change. The results showed a significant positive relationship between these two variables $(p=0.000)$ (Table 3).

Table 3. The Results of the Simple Regression Analysis for Testing the Impact of Perception of Career Development, Compensation, and Communication Practices on Employee Readiness for Change

\begin{tabular}{l|c}
\hline \multicolumn{1}{c|}{ Variable } & $\beta$ \\
\hline Career development & 0.25 \\
\hline Compensation & 0.33 \\
\hline Communication & 0.29 \\
\hline
\end{tabular}

Source: author's own research.

To test Hypothesis 3, a simple regression analysis was conducted to examine the positive impact of employees' positive perceptions of the company's communication practices on readiness for change. The results showed a significant positive relationship between these two variables $(p=0.000)$ (Table 3).

\section{Conclusion}

In today's business world human resources, which have always been central to organisations, are of rapidly growing strategic importance in change management. It is therefore the case that an organisation's ability to successfully complete a merger and acquisition is increasingly dependent on HR practices. The practices we can turn to during mergers and acquisitions to increase employee readiness include creating sufficient motivation to change employees' minds, reinforcing their inclination to be supportive by a rewards system, establishing a career path for them in the new organisation, using successful communication methods, careful and clear planning for all phases of the change project and, finally, consulting them and getting them involved in the change process. 
We have seen in this study that compensation policies have the highest impact on employee readiness for change. Turkey is an emerging economy where finding a middle level job is considered difficult and where a salary is the main source of income for most middle class families. It is therefore understandable that compensation practices would have a greater effect on employee readiness than the other variables in this study. Based on Lee and Park's research (2013), progressive HR departments strategically use incentives and rewards as a part of the total compensation package (e.g. incentive compensation, year-end bonus, retention bonus, sign-on bonus, profit sharing, spot bonus). Some organisations offer non-monetary awards, such as additional time off for outstanding accomplishments, while $72 \%$ of organisations publicly recognise employees for good work. In addition, it is as important for HR to formulate an attractive overall package as it is to strategically promote the consistent and wise use of incentive and reward programmes. Otherwise, the talent would not trust the new company formed as a result of the merger or acquisition and would consider other options.

The use of proper communication practices was found to have a positive impact on employee readiness. Communication is paramount when trying to raise the level of understanding of what the change process is and why it is needed. Proper communication is also necessary to comfort the employees. This lowers the level of stress, ambiguity and job insecurity, which are the most common outcomes of change itself, and addresses the uncertainty created by the change. Effective communication is also vital during a merger or acquisition because this is when the rumour mill, the organisation's unofficial and informal communication system, frequently serves as the main source of news. The rumours are compounded by a lack of official information, which increases the ambiguity, thus fuelling an already volatile situation. It is therefore highly recommended for managers to disseminate information about change that is comprehensive and well timed: employees need to be kept abreast of relevant issues as they arise (Davy et al. 1988).

Career development is a delicate topic in mergers and acquisitions. All employees want to know what will happen to them after a merger or acquisition has been completed. A merger or acquisition is always a tumultuous, anxious and confusing time for employees and one that raise many question marks and concerns about an individual's future. The situation can become even more stressful with employees worrying that their positions might change or be eliminated. After all, mergers and acquisitions are usually associated with redundancies due to overlaps in positions. There may also be lay-offs and employees can also be asked to switch roles. Mergers often bring 
a mixture of welcome and not-so-welcome changes to the workplace. The new company might have a different mission, different values and different goals. Employees may feel that they do not fit in with the new dispensation and may therefore trust the new organisation less and be less committed to it. This feeling may also be coloured by resistance to change. On the other hand, the new organisation might offer new opportunities or have better benefit programmes. More than that, it could offer the chance to achieve individual career goals and, rather than shedding jobs, might instead need to employ more staff or enrich existing positions (Reeves 2014). At this point, well-designed and well-implemented career-development practices make building strong relations with employees during mergers and acquisitions more likely. In this way they will be regarded as more acceptable and desirable. Attractive incentives that include the prospect of career development as a component of mergers and acquisitions are often required to keep staff focused and motivated (Connerty et al. 2013).

De Cieri and his colleagues (2003) contend that the successful implementation of change is a major challenge for HRM in the twenty-first century and one that will compel managers to actively address the issues of resistance to change, to modifying behaviour and to participation. HR professionals will, however, be well-equipped to meet this challenge and prepare their employees if they can find ways to provide security of employment and training and if they communicate effectively about change.

The implications of this study mainly concern the executives, senior managers and change agents who will be responsible for managing change at an organisation. The challenge they face is to manage the change in such a way that employees can cope. They need to help their employees to understand the reason for the change, its purpose and the overarching mission that gives it its context. In this way they can help employees find ways of responding positively so that they will lend their support to the change process. Because the readiness of employees during a merger and acquisition is of the utmost importance for the success of the deal, effective human resource management practices are indispensable. Employees need to be treated delicately and sensitively during this stressful process. This is the time when HR managers should have well-developed and well-implemented strategies in place to help their employees understand and support the change. This paper has given an account of the importance and necessity of certain human resource management practices during mergers and acquisitions. It will fall to future research initiatives to examine how different organisational cultures, national cultures and leadership styles 
influence employees' perspectives on human resource practices during mergers and acquisitions.

\section{Limitations}

The survey was distributed to three different companies. The relatively low response rates received from each company forced the author to analyse all of the responses together as if they were one group. Though this may have had some impact on the findings due to organisational differences, it nevertheless affords us a general perspective of the topic investigated in the research. The second limitation lay in the questions employees were asked about their perceptions of certain variables. Firstly, the perception of any variable can be subjective. Secondly, employees can feel uncomfortable when responding to enquiries about rewards and promotion. Finally, in the sense that employees' perception of the change as either positive or negative can affect their attitudes to mergers and the way they behave as these deals take their course, perception bias may have played a critical role when the participants were completing the survey.

\section{Bibliography}

Allen, J., Jimmieson, N. L., Bordia, P. and Irmer, B. E. (2007) "Uncertainty during Organizational Change: Managing Perceptions through Communication". Journal of Change Management 7 (2): 187-210, http://dx.doi.org/10.1080/14697010701563379.

Armenakis, A. A., Harris, S. and Field, H. (1999) "Paradigms in Organizational Change: Change Agent and Change Target Perspectives" in R. Golembiewski (ed.) Handbook of Organizational Behavior. New York: Marcel Dekker.

Armenakis, A. A., Harris, S. G. and Mossholder, K. W (1993) "Creating Readiness for Organizational Change". Human Relations 46: 681-703, http://dx.doi. org/10.1177/001872679304600601.

Birkinshaw, J., Bresman, H. and Håkanson, L. (2000) "Managing the Post-acquisition Integration Process: How the Human Integration and Task Integration Processes Interact to Foster Value Creation". Journal of Management Studies 37 (3): 395-425, http://dx.doi.org/10.1111/1467-6486.00186.

Björkman, I., Stahl, G. K. and Vaara, E. (2007) "Cultural Differences and Capability Transfer in Cross-border Acquisitions: The Mediating Roles of Capability Complementarity, Absorptive Capacity, and Social Integration". Journal of International Business Studies 38 (4): 658-72, http://dx.doi.org/10.1057/palgrave. jibs.8400287.

Blake, R. R. and Mouton, J. S. (1985) "How to Achieve Integration on the Human Side of the Merger". Organisational Dynamics 13 (3): 41-56, http://dx.doi.org/10.1016/00902616(85)90029-4. 
Bordia, P., Hobman, E., Jones, E., Gallois, C., and Callan, V. J. (2004) "Uncertainty during Organizational Change: Types, Consequences, and Management Strategies". Journal of Business and Psychology 18 (4): 507-32, http://dx.doi.org/10.1023/ b:jobu.0000028449.99127.f7.

Brief, B. (2009) The 10 Steps to Successful M\&A Integration. http://www.bain.com/ publications/articles/10-steps-to-successful-ma-integration.aspx, date of access: 3 April 2014.

Buono, A. and Bowditch, J. (1989) The Human Side of Mergers and Acquisitions: Managing Collisions between People, Cultures and Organizations. San Fraricisco, CA: Jossey-Bass.

Connerty, M., Lavoie, B., Webb, G. and McNabb, S. (2013) "Mergers \& Acquisitions: What Winners Do to Beat the Odds". L.E.K. Executive Insights 15 (16): 1-7.

Cunningham, C. E., Woodward, C. A., Shannon, H. S., MacIntosh, J., Lendrum, B., Rosenbloom, D. and Brown, J. (2002) "Readiness for Organizational Change: A Longitudinal Study of Workplace, Psychological and Behavioural Correlates". Journal of Occupational and Organizational Psychology 75: 377-92, http:/dx.doi. org/10.1348/096317902321119637.

Daniel, T. A. and Metcalf, G. S. (2001) The Management of People in Mergers and Acquisitions. Westport, CT: Quorum.

Davy, J. A., Kinicki, A., Kilroy, J. and Scheck, C. (1988) "After the Merger: Dealing with People's Uncertainty”. Training \& Development Journal 42 (11): 57-61.

De Cieri, H., Kramar, R., Noe, R. A., Hollenbeck, J. R., Gerhart, B., and Wright, P. M. (2003) Human Resource Management in Australia: Strategy, People, and Performance. Sydney: McGraw-Hill.

Delery, J. E. and Doty, D. H. (1996) "Modes of Theorizing in Strategic Human Resource Management: Tests of Universalistic, Contingency, and Configurational Performance Predictions". Academy of Management Journal 39: 802-35, http://dx.doi. org/10.2307/256713.

Fisher, J. T. (2004) "M\&A Integration at Delta Connection Inc. The Importance of Employee and Company Culture in a Corporate Transaction". Risk Finance 5 (4): 14-18.

Fulmer, R. M. and Gilkey, R. (1988) "Blending Corporate Families: Management and Organization Development in a Post-merger Environment". Academy of Management Executive 2 (4): 275-83, http://dx.doi.org/10.5465/ame.1988.4274773.

Gerhart, B. and Milkovich G. T. (1992) "Employee Compensation: Research and Theory" in M. D. Dunnette and L. M. Hough (eds) Handbook of Industrial and Organizational Psychology. Palo Alto, CA: Consulting Psychologist Press.

Gong, Y. and Chang, S. (2008) "Institutional Antecedents and Performance Consequences of Employment Security and Career Advancement Practices: Evidence from the People's Republic of China”. Human Resource Management 47 (1): 33-48, http://dx.doi.org/10.1002/hrm.20196.

Greenspan, D. S. (2014). "HR \& M\&A. 10 Critical Success Factors for Planning and Implementation". Global Business News, http://www.globalbusinessnews.net/story. asp?sid=35, date of access: 3 April 2014.

Guirdham, M. (1999) Communicating across Cultures. London: Macmillan Press Limited. 
Holt, D. T., Armenakis, A. A., Field, H. S. and Harris, S. G. (2007) "Readiness for Organizational Change: The Systematic Development of a Scale". The Journal of Applied Behavioral Science 43: 232-55, http://dx.doi.org/10.1177/0021886306295295.

Ibrahim, I. I. and Boerhaneoddin, A. (2010) "Is Job Satisfaction Mediating the Relationship between Compensation Structure and Organisational Commitment? A Study in the Malaysian Power Utility. Journal of Global Business and Economics $1(1)$ : 43-60.

Ivancevich, J. M., Schweiger, D.M. and Power, F. R. (1987) "Strategies for Managing Human Resources during Mergers and Acquisitions". Human Resource Planning Journal 10 (1): 19-35.

Jeris, L. S., Johnson, R. and Carol, C. A. (2002) "HRD Involvement in Merger and Acquisition Decisions and Strategy Development: Four Organizational and Portraits". International Journal of Training and Development 6 (1): 2-12, http://dx.doi. org/10.1111/1468-2419.00145.

Knight, S. (2014) "Employee Ownership in Career Development: The Role of the Organization". Career Convergence Magazine, http:/www.ncda.org/aws/NCDA/pt/sd/ news_article/38176/PARENT/layout details cc/false\#sthash.DRDBumiA.dpuf.

Larsson, R. and Finkelstein, S. (1999) "Integrating Strategic, Organizational and Human Resource Perspectives on Mergers and Acquisitions: A Case Survey for Synergy Realization”. Organization Science 10 (1): 1-26, http://dx.doi.org/10.1287/orsc.10.1.1.

Lee, E. and Park, H. J. (2013) "What Are Best Practices for Retaining Employees during Mergers and Acquisitions?” Cornell University ILR School DigitalCommons@ILR, http://digitalcommons.ilr.cornell.edu/student/25, date of access: 29 December 2014.

Levesque, D. A., Prochaska, J. M. and Prochaska, J. O. (1999) "Stages of Change and Integrated Service Delivery”. Consulting Psychology Journal: Practice and Research 51: 226-41, http://dx.doi.org/10.1037//1061-4087.51.4.226.

Levesque, D. A., Prochaska, J. M., Prochaska, J. O., Dewart, S. R., Hamby, L. S. and Weeks, W. B. (2001) "Organizational Stages and Processes of Change for Continuous Quality Improvement in Health Care”. Consulting Psychology Journal: Practice and Research 53: 139-53, http://dx.doi.org/10.1037//1061-4087.53.3.139.

Lips-Wiersma, M. and Hall, D. T. (2007) "Organizational Career Development is Not Dead: A Case Study on Managing the New Career during Organizational Change". Journal of Organizational Behavior 28 (6): 771-92, http://dx.doi.org/10.1002/job.446.

Madsen, S. R., Miller, D. and John, C. R. (2005) "Readiness for Organizational Change: Do Organizational Commitment and Social Relationships in the Workplace Make a Difference?". Human Resource Development Quarterly 16: 213-34, http://dx.doi. org/10.1002/hrdq.1134.

Marks, M. L. and Mirvis, P. H. (1986) “The Merger Syndrome”. Psychology Today 20 (10): $36-42$.

Miller, K. I. and Monge, P. R. (1985) "Social Information and Employee Anxiety about Organizational Change”. Human Communication Research 11: 365-86, http://dx.doi. org/10.1111/j.1468-2958.1985.tb00052.x.

Miller, V. D., Johnson, J. R. and Grau, J. (1994) "Antecedents to Willingness to Participate in a Planned Organisational Change". Journal of Applied Communication Research 22: 59-80, http://dx.doi.org/10.1080/00909889409365387.

Moran, P. and Panasian, C. (2005) The Human Side of Mergers \& Acquisitions. A Look at the Evidence. PhD Thesis. Chile: Universidad de Talca. 
Naveed, M., Hanif. M. N. and Ali, S. (2011) "Impact of Mergers \& Acquisitions on Job Security and Motivation: A Case Study of Banking Employees of Pakistan". Third International Conference on Information and Financial Engineering IPEDR, Vol. 12. Singapore: IACSIT Press.

Nemanich, L. A. and Keller, R. T. (2007) "Transformational Leadership in an Acquisition: A Field Study of Employees". The Leadership Quarterly 18: 49-68, http://dx.doi. org/10.1016/j.leaqua.2006.11.003.

Pettigrew, A. (1987) "Context and Action in Transforming the Firm". Journal of Management Studies 24: 649-70, http://dx.doi.org/10.1111/j.1467-6486.1987.tb00467.x.

Prochaska, J. O., Velicer, W. F., Rossi, J. S., Goldstein, M. G., Marcus, B. H., Rakowski, W., Fiore, C., Harlow, L. L., Redding, C. A., Rosenbloom, D. and Rossi, S. R. (1994) "Stages of Change and Decisional Balance for 12 Problem Behaviors". Health Psychology 13: 39-46, http://dx.doi.org/10.1037//0278-6133.13.1.39.

Reeves, L. (2014) “Advantages and Disadvantages of Employees of Mergers”. http://work. chron.com/advantages-disadvantages-employees-mergers-9723.html, 29 December 2014.

Roij, T. (2014) "The Role and Impact of HR in M\&A". RSA, http://www.thersagroup. com/news/ART046/, date of access: 3 April 2014.

Rosnow, R. L. (1988) "Rumor as Communication: A Contextualist Approach". Journal of Communication 38: 12-28, http://dx.doi.org/10.1111/j.1460-2466.1988.tb02033.x.

Schweiger, D. M. and Denisi, A. S. (1991) "Communication with Employees Following a Merger: A Longitudinal Field Experiment”. Academy of Management Journal 34 (1): 110-35, http://dx.doi.org/10.2307/256304.

Snell, S. A. and Dean, J. W. (1992) "Integrated Manufacturing and Human Resource Management: A Human Capital Perspective". Academy of Management Journal 35 (3): 467-504, http://dx.doi.org/10.2307/256484.

Stahl, G. and Kuhlmann, T. (2002) "Employee Development and Expatriate Assignment". Blackwell Handbook of Cross-Cultural Management 155-83.

Steers, R. M. (1977) "Antecedents and Outcomes of Organizational Commitment". Administrative Science Quarterly 22: 46-56, http://dx.doi.org/10.2307/2391745.

Wruck. K. H. (2000) "Compensation, Incentives and Organizational Change: Ideas and Evidence from Theory and Practice" in M. Beer and N. Nohria Breaking the Code of Change. Cambridge, MA: Harvard Business School Press.

Vazirani, N. (2012) "Mergers and Acquisitions Performance Evaluation. A Literature Review”. SIES Journal of Management 8 (2): 37-42.

Yean, T. F. and Yahya, K. K. (2013) "The Influence of Human Resource Management Practices and Career Strategy on Career Satisfaction of Insurance Agents". International Journal of Business and Society 14 (2): 193-206. 


\section{Abstract}

\section{Wpływ praktyk z zakresu zarządzania zasobami ludzkimi na gotowość pracowniczą do zmian w procesie fuzji i przejęć}

Jednym z czynników decydujących o sukcesie przedsiębiorstwa jest zaakceptowanie procesu ciągłej i nieprzerwanej zmiany. Badania dowodzą, że gotowości do zmiany organizacyjnej musi towarzyszyć otwartość indywidualnych pracowników, ich przygotowanie oraz chęć do zmiany. Badacze oraz praktycy są zgodni także co do tego, że podejście pracowników jest kluczowym czynnikiem sukcesu w przeprowadzaniu zmian organizacyjnych. W artykule zaprezentowano wyniki badań dotyczące znajomości stosowanych praktyk z zakresu HR przez pracowników i wpływu tych praktyk na gotowość zatrudnionych do zmian, wynikających z przygotowywanego procesu fuzji i przejęć. W prezentowanym badaniu wzięło udział 235 pracowników z trzech największych firm spożywczych w Istambule. Zebrane dane zostały poddane analizie statystycznej przy użyciu korelacji oraz regresji. Wyniki badań wskazują, że pozytywne postrzeganie stosowanych w organizacjach praktyk z zakresu rozwoju kariery, wynagradzania oraz komunikacji wpływa na gotowość pracowniczą do zaangażowania się w proces fuzji i przejęć.

Słowa kluczowe: praktyki zarządzania zasobami ludzkimi (ZZL), rozwój pracowników, praktyki wynagradzania, praktyki komunikacyjne, gotowość pracowników do zmian, fuzje i przejęcia. 